\title{
ANALISIS AGRIBISNIS KENTANG (Solanum tuberosum L) Desa: Merek, Kecamatan Merek, Kabupaten Karo, Provinsi Sumatera Utara
}

\author{
Oleh : \\ Lilis S. Gultom ${ }^{1)}$ \\ Damai Zaro Gea ${ }^{2)}$ \\ Universitas Darma Agung Medan ${ }^{1,2)}$ \\ E-mail: \\ lilis04jun@gmail.com ${ }^{1)}$ \\ damaizaragea@gmail.com $^{2)}$
}

\begin{abstract}
The aim of the research are (1) knowing the internal and external factors which are strengths, weaknesses, opportunities and threats in the development of potato agribusiness.), (2) knowing the alternatives and priorities that can be applied in the development of potato agribusiness, (3) knowing how much cost, revenue, and income of potato farming, (4) knowing Knowing the feasibility of potato farming in the study area.The research area was determined by the purposive sampling of Trademark, Trademark District, Karo District which was conducted in May 2019 - August 2019. The reason for choosing the area was because the majority of the population were cultivating potato plants. The sampling method is done by simple ranom sampling (simple random). The sample in this study were farmers who worked on potato crops throughout the year. The number of samples in this study amounted to 30 samples. The results showed that: There are internal and external factors that become strengths, weaknesses, opportunities, and threats in the development of potato agribusiness in the study area. Based on the results of the QSPM matrix analysis of the eight strategies there is one strategy that needs to be prioritized with a TAS value of 5,893. Costs used by farmers in managing their farms are Rp.17,099,180 per farmer. Revenue per farmer is Rp.59,500,000. The level of income of potato farmers in the study area is relatively high. Where the net income per farmer is Rp.42,400,820, while the $R / C$ value of potato farming is 3.48 per farmer, this shows that the $R / C$ ratio is greater than one so that the potato farming is feasible (economically profitable).
\end{abstract}

Keywords: agribusiness, farming, potatoes, income, revenue.

\begin{abstract}
ABSTRAK
Tujuan penelitian yaitu (1) Mengetahui faktor internal dan eksternal apa yang menjadi kekuatan, kelemahan, peluang dan ancaman dalam pengembangan agribisnis kentang.), (2) Mengetahui alternatif dan prioritas yang dapat diterapkan dalam pengembangan agribisnis kentang, (3) Mengetahui berapa besar biaya,
\end{abstract}


penerimaan, dan pendapatan usahatani kentang, (4) Mengetahui kelayakan usahatani kentang di daerah penelitian.Daerah penelitian ditentukan secara purposive sampling Merek, Kecamatan Merek, Kabupaten Karo yang dilaksanakan pada bulan Mei 2019 - Agustus 2019. Alasan memilih daerah tersebut karena mayoritas penduduknya mengusahakan tanaman kentang. Metode penarikan sampel dilakukan dengan cara Simple ranom sampling (acak sederhana). Sampel dalam penelitian ini adalah petani yang mengusahakan tanaman kentang sepanjang tahun. Jumlah sampel pada penelitian ini sebesar 30 sampel.Hasil penelitian menunjukan bahwa : Ada faktor internal dan eksternal yang menjadi kekuatan, kelemahan, peluang, dan ancaman dalam pengembangan agribisnis kentang di daerah penelitian. Berdasarakan hasil analisis matrik QSPM dari kedelapan strategi terdapat satu strategi yang perlu diprioritaskan dengan nilai TAS sebesar 5,893. Biaya yang digunakan petani dalam mengelolah usahataninya yaitu sebesar Rp.17.099.180per petani,. Penerimaan per petani sebesar Rp.59.500.000. Tingkat pendapatan petani kentang di daerah penelitian tergolong tinggi. Dimana pendapatan bersih per petani Rp.42.400.820, sedangkan Nilai R/C usahatani kentang adalah sebesar 3,48 per petani, hal ini menunjukan bahwa rasio $\mathrm{R} / \mathrm{C}$ lebih besar dari satu sehingga usahatani kentang tersebut layak diusahakan (menguntungkan secara ekonomi).

Kata kunci: agribisnis, usahatani, kentang, pendapatan, penerimaan.

\section{PENDAHULUAN}

\section{Latar Belakang}

Sektor pertanian mempunyai peranan penting atau kontribusi yang sangat besar dalam pembangunan ekonomi suatu Negara yang bercorak agraris seperti Indonesia. Indonesia dikenal sebagai sebagai Negara yang kaya akan sumber daya alam, yang memiliki luas lahan dan agroklimat yang potensial untuk dikembangkan sebagai usaha pertanian. Indonesia Negara agraris yang mengandalkan sektor pertanian sebagai sumber mata pencaharian dan penompang pembangunan

(Mardikanto, 2014).

Sektor agribisnis merupakan sektor ekonomi terbesar dan terpenting dalam perekonomian. Namun sektor agribisnis masih menghadapi beberapa tantangan yang perlu diatasi seperti tingkat pendapatan petani yang masih rendah, lambatnya peningkatan pertanian pada sektor tanaman pangan. Dengan demikian, pertanian harus dikembangkan tidak hanya diversifikasi (komoditas yang menguntungkan) tetapi juga meningkatkan nilai tambah terhadap produk-produk pertanian (Departemen pertanian, 2011).

Salah satu holtikultura yang prioritas untuk dikembangkan adalah kentang (Solanum tuberosum L.). Komoditas ini memiliki potensi untuk dikembangkan sebagai sumber karbohidrat yang berguna untuk menunjang program diversifikasi pangan non beras yang bernilai gizi tinggi, disamping dapat juga dijadikan bahan baku untuk industri olahan makanan (Setiadi dan Fitri,2012).

$\begin{array}{lrr}\text { Produksi tanaman } & \text { kentang } \\ \text { (Solanum tuberosum } & \text { L.) } \\ \text { berkontribusibagi } & \text { perekonomian }\end{array}$


Indonesia sebagai penyedia salah satu bahan pangan dan bahan baku industri, penyumbang PDB, penghasil devisa negara. Kontribusi di pihak masyarakat yaitu sumber pendapatan rumah tangga perdesaan, penyedia bahan pakan, menyerap banyak tenaga kerja. (Kementerian Pertanian, 2015).

Tanaman kentang (Solanum tuberosum L.) dapat menjadi bahan pangan alternatif dari beras. Hal ini dikarenakan kentang kaya karbohidrat, mengandung protein, vitamin dan mineral. Selain sebagai bahan pangan, kentang dapat juga digunakan sebagai bahan industri pati dan alkohol (Setiadi, 2012).

Adapun luas panen, produksi dan produktivitas tanaman kentang (Solanum tuberosum L.) di setiap Kecamatan yang ada di Kabupaten karo dapat dilihat pada tabel 1 .

Tabel 1. Luas Panen, Produksi Dan Produktivitas

Tanaman Kentang (Solanum tuberosum L.)di Kabupaten Karo Tahun 2017

\begin{tabular}{|c|c|c|c|c|}
\hline $\begin{array}{l}\mathrm{N} \\
\mathrm{o} .\end{array}$ & $\begin{array}{c}\text { Kecam } \\
\text { atan }\end{array}$ & $\begin{array}{c}\text { Lua } \\
\text { s } \\
\text { Pan } \\
\text { en } \\
(\mathrm{Ha} \\
)\end{array}$ & $\begin{array}{l}\text { Produ } \\
\text { ksi } \\
\text { (Ton) }\end{array}$ & $\begin{array}{l}\text { Produkti } \\
\text { vitas } \\
\text { (Ton/Ha) }\end{array}$ \\
\hline 1. & $\begin{array}{l}\text { Simpan } \\
\mathrm{g} \\
\text { Empat }\end{array}$ & 386 & 5.759 & 14,92 \\
\hline 2. & $\begin{array}{l}\text { Naman } \\
\text { Teran }\end{array}$ & 558 & 9.723 & 17,42 \\
\hline 3. & $\begin{array}{l}\text { Merdek } \\
\text { a }\end{array}$ & 530 & 8.642 & 16,30 \\
\hline 4. & $\begin{array}{l}\text { Kabanj } \\
\text { ahe }\end{array}$ & 213 & 4.260 & 20,00 \\
\hline 5. & $\begin{array}{l}\text { Berasta } \\
\text { gi }\end{array}$ & 194 & 3.048 & 15,71 \\
\hline 6. & Tigapa & 304 & 3.228 & 10,62 \\
\hline
\end{tabular}

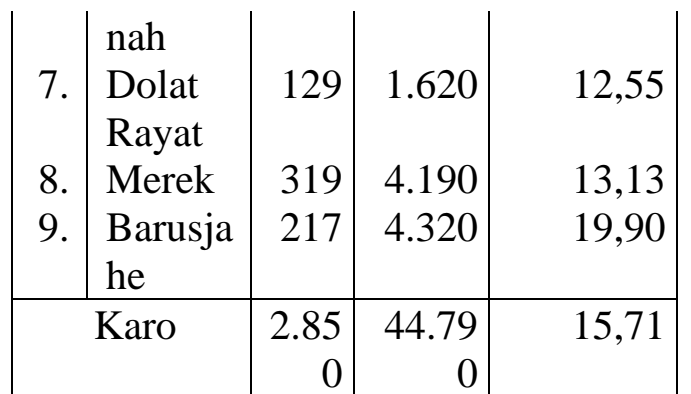

Sumber: Badan Pusat Statistik (BPS), Kabupaten Karo Dalam Angka 2018

Berdasarkan tabel diatas dapat dilihat bahwa kecamatan Merek termasuk sentra produksi Kentang (Solanum tuberosum L.) yang berada diurutan keempat setelah Kecamatan Naman Teran, Merdeka, Simpang Empat. Kecamatan Merek dengan luas panen $319 \mathrm{Ha}$, produksi sebesar 41.902 Ton dan produktivitas 131,35 Ton/Ha.

Dalam usahatani kentang (Solanum tuberosum L.) masih memiliki kendala dalam pengembangannya maka diperlukan suatu sistem yang dapat mengatasi hal tersebut. Oleh karena itu, pelaksanaan sistem agribisnis dalam usahatani kentang (Solanum tuberosum L.)mampu mengatasi hal tersebut dan sangat penting untuk diterapkan dalam mengembangkan dan meningkatkan produksi kentang (Solanum tuberosum L.). Berdasarkan penjelasan diatas, maka penulis ingin menganalisis dan tertarik untuk melakukan penelitian dengan judul Analisis Agribisnis Kentang(Solanumtuberosum L.) di Desa Merek,Kecamatan Merek, Kabupaten Karo, Provinsi Sumatera Utara.

\section{Tujuan Penelitian}

Berdasarkan identifikasi permasalahan penelitian ini bertujuan untuk : 
1. Mengetahui faktor internal dan eksternal apa yang menjadi kekuatan, kelemahan, peluang dan ancaman dalam pengembangan agribisnis kentang (Solanum tuberosum L.) di daerah penelitian.

2. Mengetahui alternatif dan prioritas yang dapat diterapkan dalam pengembangan agribisnis kentang (Solanum tuberosum $L$.)di daerah penelitian.

3. Mengetahui berapa besar biaya, penerimaan, dan pendapatan usahatani kentang (Solanum tuberosum L.)di daerah penelitian.

4. Mengetahui kelayakan usahatani kentang (Solanum tuberosum L.)di daerah penelitian?

\section{TINJAUAN PUSTAKA}

\section{Aspek Agronomis dan Ekonomis}

Tanaman kentang (Solanum tuberosum L.)merupakan bahan pangan dari umbi tanaman perennial dari family Solanaceae. Kentang (Solanum tuberosum L.)juga salah satu bahan pangan utama yang mendapatkan prioritas dalam pengembangannya di Indonesia (Samadi, 2011).

Kentang (Solanum tuberosum L.) digunakan sebagai bahan makanan sumber bahan pangan selain beras,karena kentang(Solanum tuberosum L.) kaya akan vitamin, kalium, karbohidrat dan protein. Dengan kandungan gizi yang tinggi ini, beberapa Negara-negara berkembang mengkonsumsi kentang (Solanum tuberosum L.) sebagai bahan pangannya (Setiadi, 2009).

$$
\text { Manfaat dari tanaman }
$$
kentang (Solanum tuberosum L.) dapat dioleh menjadi makanan ringan, sehingga akan meningkatkan nilai tambah kentang(Solanum tuberosum L.). Kentang (Solanum tuberosum L.) dapat diolah menjadi dodol kentang, dan keripik kentang. Dalam meningkatkan nilai tambah dari komoditi kentang. Adanya nilai tambah kentang (Solanum tuberosum L.) akan semakin meningkatkan sektor industri, sehingga usahatani kentang (Solanum tuberosum L.) semakin meningkat (Idawati, 2012). Selain itu, manfaat tanaman kentang (Solanum tuberosum L.) dalam kesehatan antara lain: mengurangi kadar kolesterol, mengurangi resiko batu ginjal, menjaga kesehatan sistem saraf dan fungsi otak, dan menurunkan tekanan darah tinggi.

\section{Faktor-Faktor Mempengaruhi Agribisnis \\ Identifikasi Faktor Internal}

Faktor internal merupakan lingkungan internal yang terdiri dari kekuatan dan kelemahan yang ada didalam organisasi tersebut tetapi biasanya tidak dalam pengendalian jangka pendek dari manajemen puncak, lingkungan internal terdiri dari keuangan dan akumulasi, SDM, pemasaran operasi, dan penelitian/pengembangan

(Soekartawi, 2012).

\section{Sumber Daya Alam dan Lingkungan}

Sumber daya alam dan lingkungan terkait erat dengan perihal ketersediaan lahan tanam untuk pengembangan tanaman. Dalam konteks ini tidak terlepas dari berbagai faktor penunjang tubuhnya tanaman dengan baik selain faktor yang bisa kita supply sendiri, seperti 
kesuburan lahan, energi sinar dalam bentuk cahaya dan panas, serta iklim atau suhu udara (Rasmulia. S, 2015).

\section{Sumber Daya Manusia}

Sumber daya manusia adalah segala kegiatan manusia yang dicurahkan dalam proses produksi untuk menghasilkan barang dan jasa.

\section{Ilmu Pengetahuan dan Teknologi}

Ilmu pengetahuan dan teknologi merupakan modal dasar yaitu sebagai pengetahuan dan teknologi yang digunakan sumber daya manusia dalam mengelola sumber daya alam. Penggunaan ilmu pengetahuan dan teknologi akan terkait dengan ketersediaan, kesesuaian, dan keberlanjutan penerapannya. Masalah mendasar yang perlu diperhatikan dalam pengembangan pengetahuan dan teknologi adalah dukungan prasarana pertanian, sehingga masih ada hambatan introduksi mesin-mesin pertanian. Pengeloalan SDA, pengaturan dan manajemen pengairan, serta jalan-jalan transportasi pertanian perlu dikelola secara sungguh dan profesional.

\section{Pemasaran}

\section{Soekartawi}

(2012), mengemukakan beberapa penyebab rantai pemasaran hasil pertanian menjadi panjang dan produsen sering diuraikan antara lain pasar yang tidak bekerja secara sempurna, lemahnya informasi pasar, lemahnya produsen dalam memanfaatan peluang pasar, lemahnya posisi produsen atau petani melakukan usahatani tidak didasarkan pada permintaan pasar melainkan karena usahatani dilakukan secara turun-temurun.

\section{Produksi}

Produksi adalah suatu kegiatan yang dikerjakan untuk menambah nilai guna suatu benda atau menciptakan benda baru sehingga lebih bermanfaat dalam memenuhi kebutuhan.

Pemberian pupuk organik cair juga aka meningkatkan hasil produksi tanaman Marpaung $\mathrm{R}$ \& Pasaribu B (2020).

\section{Kelembagaan}

Kelembagaan dalam unit ekonomi yang terkecil atau yang sering dikenal dengan istilah Wilayah Unit Desa (WILUD) dilengkapi dengan kelembagaan yang dapat melayani petani yaitu:

1. Adanya Lembaga Bank

2. Adanya Lembaga Penyuluhan

3. Adanya Lembaga Penyaluran Sarana Produksi

4. Adanya lembaga yang mampu membeli hasil pertanian yang diproduksi petani (Soekartawi, 2012).

\section{Modal Kerja Finansial}

Aspek finansial merupakan salah satu tujuan sistem agribisnis selain melestarikan lingkungan, membuka lapangan pekerjaan, mengembangkan IPTEK, membuka pasar dan mengembangkan organisasi (Rasmulia. S, 2015).

\section{Identifikasi Faktor Eksternal Pedagang Dipasar}

Strategi penguatan manajemen pengelolaan pasar dan penguatan modal bagi pedagang, 
ditunjukkan untuk pengelola pasar dan pedagang.

\section{Pedagang Besar}

Menurut Soekartawi (2012), pada distribusi melibatkan berbagai pihak atau lembaga yang meliputi : petani, grosir (pedagang besar), pedagang pengumpul dan pedagang pengecer pada jalur pemasaran kentang.

\section{Nilai Pelanggan}

Pemasaran yang baik adalah pemasaran yang bisa memenuhi kebutuhan dan keinginan pelanggan, sekaligus membangun sebuah komunikasi yang baik dengan mereka demi kepentingan perusahaan dimasa depan/lancarnya jual beli produk kentang.

\section{Penyedia Sarana Produksi}

Penyedia dan penyaluran sarana produksi mencakup semua kegiatan perencanaan, pengelolaan, pengadaan dan penyaluran sarana produksi untuk memungkinkan terlaksananya penerapan teknologi usahatani dan pemanfaatan sumber daya pertanian secara optimal (Soekartawi, 2012).

\section{Pemerintah}

Menurut Rangkuti (2014) pemerintah memiliki kedudukan yang kuat, ini merupakan sumber dana, memiliki kewenangan mempengaruhi pasar. Tinggi rendahnya bunga Bank maupun pinjaman tak sepenuhnya terlepas dari kendali pemerintah.

\section{Perbankan}

Perbankan adalah badan usaha yang menghimpun dana dari masyarakat dalam bentuk simpanan dan menyalurkannya kepada masyarakat dalam bentuk kredit atau bentuk-bentuk lainnya untuk meningkatkan tarif hidup rakyat banyak.

\section{Pengolahan Hasil Pertanian}

Menurut Seokartawi (2012), komponen pengolahan hasil pertanian menjadi penting karena berbagai pertimbangan yaitu meningkatkan nilai tambah, meningkatkan kualitas hasil, meningkatkan penyerapan tenaga kerja, meningkatkan keterampilan produsen dan meningkatkan pendapatan produsen.

\section{Alternatif dan Prioritas Strategi Pengembangan Agribisnis}

Strategi merupakan alat untuk mencapai tujuan perusahaan dalam kaitannya dengan tujuan jangka panjang, program tidak lanjut, serta prioritas alokasi sumber daya (Rangkuti, 2014).

Strategi pengembangan agribisnis bukan semata-mata persoalan manajemen bisnis ditingkat mikro, namun sangat terkait dengan formasi kebijakan ditingkat makro serta kemampuan mensiasati dan menemukan strategi ditingkat entrepreneur. Keterpaduan formasi makro-makro ini sangat diperlukan, mengingat agribisnis adalah suatu rangkaian sistem usaha berbasis pertanian dan sumber daya lain dari hulu sampai hilir (Rangkuti, 2014).

\section{Faktor Produksi \\ Lahan}

Faktor produksi dalam usaha tani kentang mencakup ke tanah. Tanah merupakan faktor fungsi 
dalam pertanian, selain tanah banyak faktor yang harus diperhatikan seperti luasnya, kesuburannya, lingkungannya, keadaan fisiknya dan lain sebagainya. Dengan mengetahui keadaan semua tanah, usaha pada pertanian akan dapat dilakukan dengan baik (Daniel, 2015).

\section{Tenaga Kerja}

Tenaga kerja merupakan faktor produksi yang penting dan perlu diperhitungkan dalam proses produksi. Dalam usaha tani curahan tenaga kerja yang tepat akan memberikan dampak positif terhadap peningkatan produksi usahatani. Dalam usahatani dikenal dengan istilah pencurahan tenaga kerja yaitu jumlah tenaga kerja yang terlibat dalam kegiatan usahatani baik yang berasal dari tenaga kerja dalam keluarga (TKDK) maupun tenaga kerja luar keluarga (TKLK) (Hernanto, 2011).

\section{Bibit}

Bibit adalah faktor produksi usahatani yang penting pada suatu tanaman karena bibit merupakan awal kehidupan tanaman tersebut. Bibit adalah benih tanaman yang sudah tumbuh dan memenuhi persyaratan untuk digunakan sebagai bahan pertanaman selanjutnya. (Soekartawi, 2012).

\section{Pupuk}

Pupuk merupakan bahan yang akan diberikan ke dalam tanah baik organik maupun non organik dengan maksud untuk mengganti kehilangan unsur hara dari dalam tanah yang bertujuan untuk meningkatkan produksi tanaman.

\section{Pestisida}

Pestisida merupakan substans yang digunakan untuk membunuh atau mengendalikan berbagai jenis hama seperti tungau, tumbuhan pengganggu, penyakit tanaman yang disebabkan oleh fungi, bakteri, tikus, burung, nematode dan yang lain yang dianggap merugikan pada tanaman.

\section{Peralatan}

Peralatan adalah segala sesuatu jenis alat yang akan digunakan dalam suatu usahatani. Banyak tidaknya peralatan dipengaruhi oleh luas lahan, semakin luas lahan maka peralatan akan semakin banyak untuk diperlukan. Dalam suatu usaha tani semakin banyak peralatan maka biaya penyusutan akan semakin tinggi. Biaya penyusutan ini tergantung pada harga dan umur ekonomis yang digunakan (Soekartawi, 2012).

\section{Pendapatan Usahatani}

Pendapatan bersih adalah penerimaan dikurangi dengan biaya produksi. Petani dalam memperoleh pendapatan bersih yang tinggi maka petani harus mengupayakan penerimaan yang tinggi dan biaya produksi yang rendah dengan mengatur biaya produksi. Menggunakan teknologi yang baik, mengupayakan harga input yang rendah, dan mengatur skala produksi yang efisien. (Soekartawi, 2012).

Pendapatan usahatani merupakan suatu gambaran berhasil tidaknya usahatani yang dijalankan petani. Pendapatan usahatani adalah selisih antara penerimaan dengan semua biaya produksi atau secara sistematis : 


$$
\mathbf{P d}=\mathbf{T R}-\mathbf{T C}
$$

Dimana :

$$
\begin{array}{ll}
\mathrm{Pd} & =\text { Pendapatan Usahatani } \\
\mathrm{TR} & =\text { Total Penerimaan } \\
\mathrm{TC} & =\text { Total Biaya }
\end{array}
$$

\section{Kelayakan Usahatani}

Dalam mengetahui kelayakan usahatani digunakan analisis $\mathrm{R} / \mathrm{C}$ (Return Cost Ratio) dengan menggunakan rumus :

$\mathrm{R} / \mathrm{C}$ ratio $=\frac{\text { Penerimaan }}{\text { Biaya produksi }}$

\section{METODE PELAKSANAAN}

Penelitian dilakukan di Desa

Merek, Kecamatan Merek, Kabupaten Karo. Penentuan lokasi penelitian dilakukan secara purposive sampling yang artinya bahwa daerah penelitian ditentukan dengan secara sengaja sebagai tempat pengambilan sampel dan tempat mewakili semua populasi. Adapun penentuan dan penetapan daerah tersebut sebagai daerah penelitian karena Desa Merek, Kecamatan Merek, Kabupaten Karo, Provinsi Sumatera Utara merupakan salah satu sentral produksi tanaman kentang. Waktu penelitian dilaksanakan mulai bulan Mei 2019 sampai Agustus 2019.

Jumlah sampel yang diambil dari keseluruhan populasi yaitu sebanyak 39 sampel. Metode analisis data dilakukan dengan SWOT dan deskriptif.

\section{HASIL DAN PEMBAHASAN}

Faktor Internal dan Faktor Eksternal Agribisnis Kentang (Solanum tuberosum L) di Desa Merek, Kecamatan Merek, Kabupaten Karo Identifikasi Faktor Internal
Identifikasi faktor internal pengembangan agribisnis kentang di daerah penelitian terdiri dari faktor kekuatan dan kelemahan pada agribisnis kentang yang berasal dari dalam pelaku agribisnis kentang seperti sumber daya alam (SDA) sumber daya manusia (SDM), ilmu pengetahuan dan teknologi, pemasaran kentang, produksi kentang, kelembagaan dan modal kerja finansial.

\section{Identifikasi Faktor Eksternal}

Identifikasi faktor eksternal pengembangan agribisnis kentang didaerah penelitian terdiri dari faktor peluang dan ancaman pada agribisnis kentang yang berasal dari luar yang akan mempengaruhi pelaku agribisnis kentang seperti pedagang kentang dipasar, pedagang kentang besar, nilai pelangan, pemerintah, penyedia sarana produksi, perbankan dan pengolahan hasil pertanian.

Model matriks SWOT ini dapat digambarkan secara jelas peluang dan ancaman eksternal dihadapi sehingga dapat disesuaikan dengan kekuatan dan kelemahan yang dimiliki. Setelah menentukan komponen-komponen internal (kekuatan dan kelemahan) dan eksternal (peluang dan ancaman) maka diperoelh beberapa alternatif strategi yang dapat dipertimbangkan, antara lain:

Tabel 2. Matriks SWOT

Pengembangan Agribisnis Kentang, Tahun 2019

\begin{tabular}{|c|c|c|}
\hline & $\begin{array}{c}\text { Kekuatan } \\
\text { (Strenght) }\end{array}$ & $\begin{array}{c}\text { Kelemahan } \\
\text { (Weaknes) }\end{array}$ \\
\hline Peluang & Strategi S - O & Strategi W - O \\
(Oppor & $\bullet$ Mengoptimalkan \\
tunities & Meningkatakan \\
penggunaan & pendidikan \\
) & saranaproduski & petani, \\
\hline
\end{tabular}




\begin{tabular}{|c|c|c|c|c|}
\hline $\begin{array}{c}\text { Anca } \\
\text { man } \\
\text { (Treat } \\
\text { h) }\end{array}$ & $\begin{array}{l}\text { agar daya tahan } \\
\text { tanah selalu } \\
\text { terjaga untuk } \\
\text { menghasilkan } \\
\text { produki yang } \\
\text { tinggi, serta } \\
\text { mengoptimalkan } \\
\text { pengalaman } \\
\text { petani dalam } \\
\text { usahatani untuk } \\
\text { menigkatakan } \\
\text { keterjaminan } \\
\text { kentang yang } \\
\text { selalu ada (S1, } \\
\text { S2, S3, 01, 02, } \\
\text { 04) dalam } \\
\text { - Aktif kelembagaan } \\
\text { kelemban } \\
\text { kelompok tani } \\
\text { dan membangun } \\
\text { hubungan baik } \\
\text { petani dengan } \\
\text { pihak lain, agar } \\
\text { modal yang } \\
\text { dibutuhkan petani } \\
\text { dalam } \\
\text { usahataninya } \\
\text { mudah sdiperoelh } \\
\text { serta } \\
\text { keterjaminan } \\
\text { penyediaan } \\
\text { saprodi yang akan } \\
\text { meningkatakan } \\
\text { produksi kentang } \\
\text { yang dihasilkan } \\
\text { menjadi lebih } \\
\text { tinggi (S3, S4, } \\
\text { S5, 01, 02, 0,4, } \\
\text { 05) } \\
\text { Strategi S } \\
\text { Aktif } \\
\text { kelembagaan } \\
\text { pertanian dan } \\
\text { adanya hubungan } \\
\text { baik antara petani }\end{array}$ & \begin{tabular}{|l|} 
mengurangi \\
ketergantungan \\
petani kepada \\
pedagang, serta \\
menjaga \\
ketersediaan air \\
selama \\
pertanaman \\
yang akan \\
meningkatkan \\
produksi dan \\
kualitas kentang \\
yang dihasilkan, \\
sehingga \\
permintaan \\
kentang akan \\
menigkat (W1, \\
W2, W3, 01,02) \\
Melakukan \\
pengembangan \\
peralatan \\
usahatani dan \\
menjual bibit \\
kepada petani \\
serta pemasaran \\
kentang yang \\
luas agar \\
terlaksana \\
komitmen \\
pemerintah \\
dalam \\
mengembangka \\
n kios pertanian \\
(W1, W2, W5, \\
O1, O3, O4)
\end{tabular} & $\begin{array}{l}\text { dengan pihak lain. } \\
\text { Adanya fluktuasi } \\
\text { harga saprodi } \\
\text { yang dapat } \\
\text { mengurangi } \\
\text { produksi dan } \\
\text { perpindahan } \\
\text { konsumen } \\
\text { membeli kentang } \\
\text { ke daerah lain } \\
\text { dapat mengurangi } \\
\text { permintaan } \\
\text { kentang didaerah } \\
\text { penelitian (S3, S4, } \\
\text { T1, T3, T5) } \\
\text { - Memanfaatkan } \\
\text { hubungan antara } \\
\text { petani dengan } \\
\text { pihak lain yang } \\
\text { dilakukan dengan } \\
\text { penyediaan sarana } \\
\text { produksi oleh } \\
\text { pihak penyedia, } \\
\text { sehingga akan } \\
\text { dihasilkan } \\
\text { produksi dan } \\
\text { mutu kentang } \\
\text { yang baik. Hal ini } \\
\text { akan menjamin } \\
\text { harga kentang } \\
\text { tetap komperatif } \\
\text { dengan produk } \\
\text { dari luar daerah } \\
\text { penelitian yang } \\
\text { akan mencegah } \\
\text { konsumen pindah } \\
\text { ke kentang di } \\
\text { daerah lain. Hal } \\
\text { ini Tapat } \\
\text { terlaksana dengan } \\
\text { adanya dukungan } \\
\text { dari pemerintah } \\
\text { dalam pemeberian } \\
\text { modal (S3, S4, } \\
\text { S5, T1, T2, T3, } \\
\text { T4, T5) }\end{array}$ & $\begin{array}{l}\text { mengurangi } \\
\text { yang terkait } \\
\text { fluktuasi harga } \\
\text { saprodi dan } \\
\text { harga kentang } \\
\text { yang } \\
\text { komperatif } \\
\text { (W1, T1, T5) } \\
\text { Melakukan } \\
\text { modernisasi } \\
\text { peralatan } \\
\text { usahatani dan } \\
\text { mengurangi } \\
\text { ketergantungan } \\
\text { petani terhadap } \\
\text { pedagang, agar } \\
\text { mengurangi } \\
\text { pilihan kan } \\
\text { konsumen } \\
\text { pindah kari } \\
\text { kentang daerah } \\
\text { luar } \\
\text { (W1, T3) }\end{array}$ \\
\hline
\end{tabular}


1. Strategi S-O (StrenghtOpportunities)

\section{Strategi S-O adalah} menggunakan kekuatan internal untuk mengambil keuntungan dari peluang yang ada. Alternatif S-O dapat dirumuskan sebagai berikut:

a. Mengoptimalkan pertumbuhan tanaman kentang untuk menghasilkan umbi yang lebih berkualitas, Ketersediaan saprodi, kebutuhan konsumsi dan permintaan kentang yang tinggi, meningkatkan produktivitas kentang dan meningkatkan pendapatan petani (S1, S3, O1, $\mathrm{O} 2, \mathrm{O} 4)$

b. Menjaga dan mempertahankan hubungan baik petani dengan pihak lain (penyedia saprodi, pemerintah) untuk mendapatkan kemudahan akses dalam permodalan (S4, S5, O4, O5)

2. Strategi W-O

Strategi W-O adalah strategi meminimalkan kelemahan untuk memanfaatkan peluang. Alternatif strategi $\mathrm{W}-\mathrm{O}$ yang dapat dirumuskan adalah:

a. Memanfaatkan pembangunan dan pengembangan kios pertanian dengan melakukan sosialisasi tentang pembangunan dan pengembangan kios pertanian kepada petani untuk di implementasikan. (W2, W3, O2)

b. Memanfaatkan ketersediaan saprodi, akses perbankan untuk menigkatkan pengembangan agribisnis kentang (W2, O4,)

3. Strategi S-T (Strenght-Threats) Strategi S-T adalah mengoptimalkan kekuatan internal dalam menghindari ancaman.
Alternatif strategi S-T yang dapat dirumuskan adalah:

a. Aktif dalam kelembagaan pertanian dan adanya hubungan baik antara petani dengan pihak lain. Adanya fluktuasi harga saprodi yang dapat mengurangi produksi dan perpindahan konsumen membeli kentang ke daerah lain dapat mengurangi permintaan kentang didaerah penelitian (S3, S4, T1, T, T5)

b. Menjaga hubungan antara petani dengan pihak lain, agar menghasilkan produksi dan mutu kentang yang baik (S4,T1, T2, T4)

c. 4. Strategi W-T (WeaknessThreats)

Strategi W-T adalah strategi defenisi untuk meminimalkan kelemahan internal dan menghindari ancaman eksternal. Alternatif strategi yang dapat dirumuskan adalah:

a. Menigkatkan kemampuan petani untuk menigkatkan agribisnis kentang (W1, T1)

b. Melakukan modernisasi peralatan usahatani dan mengurangi ketergantungan petani terhadap pedagang, agar mengurangi pilihan konsumen pindah ke kentang dari luar daerah (W1, T3)

Biaya Produksi, Penerimaan, dan Pendapatan Usahatani Kentang (Solanum tuberosum L) di Daerah Penelitian

Penerimaan usahatani bersumber dari penjualan produksi umbi kentang. Di daerah penelitian, produksi kentang dijual kepedagang dengan harga Rp.7.000/kg setiap musim tanam. Pendapatan bersih diperoleh dengan mengurangkan seluruh biaya produksi dari 
penerimaan. Hasil perhitungan selengkapnya dapat dilihat pada tabel 3.
Tabel 3.
Penerimaan dan
Pendapatan Bersih ( $R p)$ pada
Usahatani Kentang (Solanum
tuberosum L) di Desa Merek Per
Musim Tanam Tahun 2019

atau petani dapat menabung sebagian dari pendapatanya. Untuk lebih jelasnya dapat dilihat pada tabel 4 .

Tabel 4. Penerimaan dan

Biaya Produksi pada Usahatani Kentang (Solanum tuberosum L) di Desa Merek Per Musim Tanam Tahun 2019

\begin{tabular}{|c|c|c|c|c|c|c|}
\hline \begin{tabular}{c|} 
No \\
.
\end{tabular} & Jenis & $\begin{array}{c}\text { Per } \\
\text { Petani }\end{array}$ & \begin{tabular}{c|c} 
Per & No \\
Hektar
\end{tabular} & Jenis & Per Petani & $\begin{array}{c}\text { Per } \\
\text { Hektar }\end{array}$ \\
\hline 1. & Produksi & 8.500 & $11.486,48651$. & Penerimaan & 59.500 .000 & 80.405 .405 \\
\hline 2. & Harga Jual & 7.000 & 7.0002 & Biaya & & \\
\hline 3. & Penerimaan & 59.500 .0 & & Produksi & 17.099 .180 & 23.107 .000 \\
\hline & & 00 & 80.405 .4053$. & $\mathrm{R} / \mathrm{C}$ & 3,48 & 3,48 \\
\hline 4. & Biaya Produksi & $\begin{array}{r}17.099 .1 \\
80\end{array}$ & \multicolumn{4}{|c|}{$\begin{array}{l}\text { Sumber : Data diolah, Tahun } 2019 \\
\text { 23.107.000 }\end{array}$} \\
\hline 5. & $\begin{array}{l}\text { Pendapatan } \\
\text { Bersih }\end{array}$ & $\begin{array}{r}42.400 .8 \\
20 \\
\end{array}$ & $\begin{array}{r}57.298 .405 \\
\text { ni }\end{array}$ & \multicolumn{3}{|c|}{$\begin{array}{l}\text { Dari tabel } 4 \text { diketahui bahwa } \\
\text { R/C usahatani kentang adalah }\end{array}$} \\
\hline
\end{tabular}

Sumber : Data diolah, Tahun 2019

Dari tabel 3. terlihat bahwa petani kentang memperoleh penerimaan sebesar Rp.59.500.000 per petani satu musim Tanam atau Rp.80.405.405 per hektar per musim tanam. Pendapatan bersih yang diperoleh petani adalah Rp.42.400.820 per petani atau Rp.57.298.405 per hektar satu musim tanam. Hal ini dapat disimpulkan bahwa penerimaan dan pendapatan bersih petani kentang di daerah penelitian sudah tergolong tinggi, jika dibandingkan dengan UMK Kabupaten Karo sebesar Rp.2.829.558/bulan.

\section{Kelayakan Usahatani Kentang}

Kriteria pengukuran usahatani yang digunakan pada usahatani kentang di daerah penelitian adalah rasio R/C. Jika rasio $\mathrm{R} / \mathrm{C}$ lebih besar dari satu maka usahatani tersebut layak untuk diusahakan dimana petani menikmati keuntungan dari hasil usahataninya sebesar 3,48 satu musim tanam. Hal ini menunjukan bahwa rasio $\mathrm{R} / \mathrm{C}$ lebih besar dari satu sehingga usahatani kentang tersebut layak diusahakan (menguntungkan secara ekonomi). Rasio R/C dipengaruhi oleh penggunaan sarana produksi. Jika penggunaan sarana produksi lebih besar, maka nilai rasio $\mathrm{R} / \mathrm{C}$ juga akan semakin rendah. Disamping itu nilai $\mathrm{R} / \mathrm{C}$ sangat dipengaruhi oleh produksi dan harga kentang pada saat panen. Jika harga kentang semakin meningkat maka nilai $\mathrm{R} / \mathrm{C}$ juga akan semakin meningkat. Pada satu musim tanam, setiap penggunaan biaya produksi sebesar satu rupiah menghasilkan penerimaan sebesar 3,48 rupiah dan pendapatan bersih sebesar 2,48 rupiah.

\section{KESIMPULAN}

1. Faktor-faktor internal dan eksternal untuk pengembangan agribisnis kentang di daerah penelitian sebagai berikut: 
a. Kekuatan : Kesuburan tanah yang cocok untuk budidaya kentang, Pengalaman dalam berusahatani kentang, Jumlah Produksi yang tinggi,Adanya hubungan yang baik antara petani dengan pihak lain (Penyedia saprodi, Pemerintah, dan Perbankan, Permodalan memadai

b. Kelemahan : Pendidikan petani yang masih rendah, Penggunaan teknologi masih sederhana, Pemasaran hasil yang masih terbatas, Tidak tahan terhadap iklim, Kurangnya akses informasi pasar.

c. Peluang : Permintaan kentang selalu tinggi, Kebutuhan mengkonsumsi tinggi, Komitmen pemerintah untuk mengembangkan kios pertanian, Ketersediaan sarana produksi selalu ada, Adanya kemudahan akses perbankan untuk permodalan.

d. Ancaman : Harga kentang dari luar komperatif, Pesaing banyak, Pilihan pelanggan pindah ke kentang diluar daerah penelitian, Kurangnya perhatian pemerintah tentang pemberian modal dan lemahnya kordinasi antar lembaga terkait, Adanya fluktuasi harga sarana produksi.

2. Dari delapan alternatif strategi yang ada terdapat satu prioritas strategi yang paling sesuai untuk diterapkan dalam upaya pengembangan agribisnis kentang di daerah penelitian yaitu menigkatkan modal dan kemampuan petani untuk menghasilkan produksi dan kualitas umbi kentang yang baik.

3. Total biaya produksi kentang didaerah penelitian tinggi di setiap musim tanam. Penerimaan usahatani kentang di daerah penelitian juga tergolong tinggi permusim tanam dan pendapatan petani di daerah penelitian pada setiap musim tanam juga tergolong tinggi.

4. Usahatani kentang didaerah penelitian layak untuk diusahakan dengan nilai $\mathrm{R} / \mathrm{C}>1$ yaitu sebesar 3,48 .

\section{DAFTAR PUSTAKA}

BPS, (2018). Sumatera Utara dalam angka 2018. Badan Pusat Statistik Sumatera Utara.

BPS, (2018). Kabupaten Karo dalam angka 2018. Badan Pusat Statistik Kabupaten Karo.

BPS, (2018). Statistik Indonesia Tahun 2018. Badan Pusat Statistik Sumatera Utara.

Budi, S. (2012). Usahatani Kentang. Yogyakarta: Kanidius.

David, (2010). Strategic Management. Jakarta : Salemba Empat.

Daniel, M. (2015). Pengantar Ekonomi Pertanian. Jakarta : PT. Bumi Aksara.

Departemen Pertanian, (2011). Kebijakan teknis Pengembangan Usaha Agribisnis Perdesaan. Departemen Pertanian RI. Jakarta. 
Freddy, Rangkuti. (2014). Analisis SWOT Teknik Membedah Kasus Bisnis Reorientasi Konsep Peremcanaan Strategis Untuk Menghadapi Abad 21. Jakarta : Gramedia Pustaka Utama.

Husado.S.et al, (2009). Pertanian Mandiri Pandangan Strategi Para Pakar Untuk Kemajuan Pertanian Indonesia. Jakarta : Penebar Swadaya,

Hernanto, F. (2011). Ilmu Usahatani. Jakarta : Penebar Swadaya.

Idawati, N. (2012). Pedoman Lengkap Bertanam Kentang: Langkah Mudah. Budidaya Kentang dan Kiat Bisnis Olahan

Kentang. Pustaka Baru, Yogyakarta.

Kementerian Pertanian, (2015). Rencana Strategi Kementerian Pertanian. Jakarta: Kementerian Pertanian RI.

Krisnamurti, Bayu dan A. Azis. (2011).

Agribisnis.Jakarta:Yayasan Pengembangan Sinar Tani.

Mardikanto, Tatok. (2014). Pengantar Ilmu Pertanian. Surakarta : Puspa.

Rukmana, R. (2013). Usahatani Kentang. Kanisius, Jakarta.

Rubatzky, V. E dan M. Yamaguchi, (2007). Sayuran dunia,
Prinsip, Produksi, dan Gizi. Bandung :ITB Press.

Rasmulia. S, (2015). Management Agribisnis. Penerbit LGMLaGods Publishing.

Samadi, (2011). Budidaya Kentang. Jakarta: Penebar Swadaya.

Setiadi dan S.F. Nurulhuda, (2009). Kentang, Varietas dan Pembudidayaan.

Jakarta:Penebar Swadaya.

Setiadi dan Fitri, S. N, (2012). Varietas dan Pembudidayaan Kentang. Jakarta: Penebar Swadaya.

Suryana, Ahmad, (2008). Kapita selekta, evolusi Penilaian Ketahanan Pangan. Yogyakarta.

Soekartawi, (2012). Ilmu Usahatani. Jakarta : Universitas Indonesia.

Marpaung, R., \& Pasaribu, B. (2020). RESPON PERTUMBUHAN DAN PERKEMBANGAN SAYUR PELENG (Spinacia oleracea) TERHADAP PEMBERIAN PUPUK ORGANIK CAIR PADA BERBAGAI MULSA. Jurnal Darma Agung, 28(1), 116 - 131. doi:10.46930/ojsuda.v28i1.51 9 